Arkiv. Tidskrift för sambällsanalys, nr 6 (2016)

Festskriftsavdelning: Göran Therborn 75 år

\title{
På spaning efter den tid som kommer
}

\section{Mats Svegfors}

SAMMANDRAG: Mats Svegfors, publicist och ämbetsman hemmahörande i motsatt politiska läger från Göran Therborn, analyserar i sin artikel i denna "festskriftsavdelning" den politiska och sociala situationen i Sverige i dag och de utvecklingslinjer som leder in i framtiden. Med utgångspunkt i den egna långa erfarenheten av statligt utredningsarbete, bland annat i den statliga Ansvarskommittén där Svegfors var ordförande, och i dialog med Therborns senare verk (bl.a. artiklarna om det tjugoförsta århundradets klasser och massor i Arkiv nr 3 20I4) skärskådas förutsättningarna för framtidens välfärdsstat. Svegfors tar fasta på Therborns fråga om medelklassen kommer ställa sig med oligarkin mot de fattiga eller med folket mot oligarkin och menar att medelklassens egenintresse klart borde tala för ett förnyat engagemang för den skattefinansierade välfärden.

NYCKELORD: Göran Therborn; framtidsstudier; välfärdsstat; medelklass; politik. PUBLICERINGSHISTORIK: Originalpublicering.

MATS SVEGFORS är ledamot av Ingenjörsvetenskapsakademien och av styrelsen för Lunds universitet.

FÖRSLAG PÅ KÄLLANGIVELSE:

Svegfors, Mats (2016) "På spaning efter den tid som kommer", i Arkiv. Tidskrift för samhällsanalys, $\mathrm{nr}$ 6, s. 73-89. DoI: http://dx.doi.org/I0.13068/2000-6217.6.4

(C) Mats Svegfors/Arkiv förlag \& tidskrift 2016 (publicerad 7 oktober 20I6)

Artikeln distribueras enligt en upphovsrättslicens från Creative Commons: Erkännande-Ickekommersiell-IngaBearbetningar 3.o Unported, som medger fri ickekommersiell användning och spridning i oförändrat skick så länge källan anges. 
Arkiv. Tidskrift för samhällsanalys är en sakkunniggranskad vetenskaplig tidskrift för samhällsvetenskap och historia. Samtliga artiklar publiceras fritt tillgängliga på:

www.tidskriftenarkiv.se

Beständig länk, DoI: http://dx.doi.org/IO.I3068/2000-62I7

Den här artikeln finns tillgänglig i följande format:

PDF \& HTML: via beständig länk, DOI: http://dx.doi.org/IO.I3068/2000-6217.6.4 EPUB: ingår i e-boksutgåva av numret, ISBN: 978 9I 79242794

TRYCK: ingår i bokutgåva av numret, ISBN: 978 9I 7924280 O

Grafisk utformning och sidnumrering är identisk i pdf och tryck.

Samtliga artiklar i nr 6 (20ı6) nås via beständig länk, DOI: http://dx.doi.org/I0.I3068/2000-6217.6

Arkiv. Tidskrift för sambällsanalys ISSN: 2000-62I7 (för elektronisk resurs)

ISSN: 2000-6225 (för tryckta nummer)

ges ut av

Stiftelsen Arkiv för främjande och spridning av samhällsvetenskaplig och historisk forskning

genom

Arkiv förlag \& tidskrift

Box 1559

SE-22I OI Lund

ВESÖK: L Gråbrödersg 3 c, ipg

TEL: 046-I3 3920

ARKIV FÖRLAG: arkiv@arkiv.nu·www.arkiv.nu

TIDSKRIFTEN ARKIV: red@tidskriftenarkiv.se · www.tidskriftenarkiv.se

ANSVARIg UTGIVARE \& CHEFREDAKTÖR: Sven Hort

ADMINistrativ RedAKTÖr: David Lindberg

ReDAKTörer: Paavo Bergman, Lisa Kings, Zhanna Kravchenko 


\title{
På spaning efter den tid som kommer
}

\author{
MATS SVEGFORS
}

Det var på hösten 197I. Lunds radikala studenter hade utlyst hyresstrejk. Jag var ordförande i studentkåren och vice ordförande i Akademiska föreningens bostäder, den stora studentbostadsstiftelsen i Lund. På ett möte i ett av bostadsområdena skulle jag företräda hyresvärden. Men innan mötet inleddes begärde en tämligen vildvuxet radikal student ordet och krävde en redogörelse för min sociala och ekonomiska bakgrund. "Annars kan vi ju inte klassbestämma dig."

Jag tyckte då att marxismen hade dragit iväg väl långt med min studentgeneration. Nog hade den vildvuxne förläst sig på Marx, Engels och, eftersom vi var i Lund, Therborn. Det var då fem år sedan Göran Therborn hade stått som redaktör för debattboken En ny vänster, som fått stor betydelse för vänsterns utveckling i Sverige. 197I hade Göran Therborn lyft sig ur dagsaktualiteterna och inlett sin väg mot internationell prominens som en av de internationellt mest intressanta marxistiska sociologerna. De arbetare i vingården som gjorde tjänst i dagsdebatten och vid Lundavänsterns bokbord då var bland andra Svante Nordin, Lennart Berntson, Håkan Arvidsson, Herman Schmid, Lars Dencik, Jan Annerstedt, Per Lysander och Gunnar Wetterberg.

Ett antal år senare, då jag var chef för ledaravdelningen på obundet moderata Svenska Dagbladet, blev jag uppringd av en programansvarig 
i en moderatförening någonstans i Halland. Han ville att jag skulle komma och tala i hans moderatförening. Och jag kunde inte gärna säga nej, tyckte han. Vi kände ju varandra. Han hade företrätt de hyresstrejkande radikala studenterna i förhandlingar med Akademiska föreningens bostäder i början av 1970-talet. Han hade suttit mitt emot mig vid förhandlingsbordet.

$\mathrm{Nu}, 45$ år senare, tycker jag inte att den vildvuxet radikales fråga om min klassbakgrund hösten I97I var så omotiverad. Även om han och den moderate styrelseledamoten i Halland inte var samma person så berättar de i mitt minne något gemensamt och väsentligt om sociala och politiska förhållanden i efterkrigstidens Sverige.

Från icke-marxistiska utgångspunkter har jag rätt ofta funderat på vad min sociala bakgrund och tillhörighet har betytt för mig och för det jag har gjort under min aktiva tid. Jag växte upp på en liten ort i Småland. Min pappa var chef för ett av ortens större företag. Han var ledande kommunalpolitiker för Högerpartiet. För de cirka hundra anställda han hade under sig var han Chefen med stor bokstav. Jag är uppväxt med ett uppifrånperspektiv, inte ringaktande eller utan medkänsla, men likväl ett uppifrånperspektiv.

Samtidigt var min pappa anställd, vi bodde i en tjänstebostad. Det fanns inte mycket mer pengar på min pappas bankkonto än att det nästan var rensat när familjen köpte sin första bil 1954 och sedan återigen när familjen köpte sin första tv 1959. (Den kostade I 750 kr, cirka 2I 000 $\mathrm{kr}$ i dagens penningvärde.) Efter att det företag han var anställd i hade köpts upp av ett större investmentföretag manövrerades han ut och fick sluta sitt arbete vid 6I års ålder. Han var självfallet inte ansluten till någon fackförening. Men han hade en sådan position att han inte ställdes på bar backe. Han pensionerades i förtid. Han hade haft tjänstebostad i praktiskt taget hela sitt liv. Mina föräldrar köpte ett litet egnahem när min pappa pensionerades. För första gången i sitt liv ägde han något som hade ett värde att tala om.

Utan min klassbakgrund hade jag knappast läst juridik, knappast gått med i Konservativa studentföreningen i Lund, knappast blivit studentkårsordförande för det studentfackliga kårpartiet Fris, knappast dragits in i det nationella nätverk av liberalkonservativa studenter där Ulf 
Adelsohn, Anders Wijkman, Peje Emilsson, Carl Cederschiöld och Carl Bildt var de dominerande namnen. Under stora delar av mitt liv har jag sedan i en mycket allmän mening tjänat kapitalet: som politisk medarbetare till en moderat ekonomiminister, som hög ämbetsman i en senare borgerlig regering, som politiskt ansvarig för den stora högertidningen, som chefredaktör för samma tidning i nästan tio år.

Men det lite besvärliga, i ett mer renodlat marxistiskt perspektiv, är att jag aldrig i någon rimlig mening har tillhört en klass av kapitalister. Jag har nästan alltid haft stor makt: som chef, som gynnad på arbetsmarknaden och inte minst som opinionsbildare. Men jag har väsentligen varit egendomslös.

Göran Therborn har hela sitt liv som forskare försökt tillämpa marxismen på det moderna samhället. Hur ska man förstå klasserna i ett samhälle där medelklassen, eller mellanskiktet, har blivit drivande i samhället? Genom mitt liv och min gärning illustrerar jag det therbornska dilemmat. En klass som inte finns och som jag tillhör bär upp makten.

I sen tid har Göran Therborn väl formulerat dilemmat, eller kanske snarare den avgörande frågan: Ställer sig medelklassen med oligarkin mot de fattiga eller med folket mot oligarkin?

Jag tror att Göran Therborns fråga mycket väl kan visa sig vara den rätta att ställa, inte bara i en teoretisk mening utan också i en mycket direkt och praktisk mening.

Men innan jag gör en ansats att besvara den frågan, och andra frågor om politiken, finns det anledning att beskriva den politiska och sociala situationen i Sverige 2016.

Det kan förefalla betydelselöst, men är det kanske ändå inte helt. Familjen Proust bodde på 9 boulevard Malesherbes när Marcel Proust var barn. Det är tre kvarter från 22 rue d'Astorg i Paris, där jag skriver dessa ord. I vuxen ålder, mellan 1906 och 1919, bodde Marcel Proust på I02 boulevard Haussmann, två kvarter från 22 rue d'Astorg. Där skrev han Swanns värld och I skuggan av unga flickor i blom, de två första delarna av romansviten Pà spaning efter den tid som flytt. 
I sina böcker gav Marcel Proust liv åt en då nyss förgången tid. Första världskriget blev den stora vattendelaren i europeisk historia. Krigsutbrottet I9I4 markerade slutet på en vacker epok. Europa hade under slutet av I800-talet och början av I900-talet varit öppet och framtidstron stark. Kultur och nöjesliv hade blomstrat.

Även om det är att bruka schabloner: åren från första världskrigets utbrott och till fredsslutet efter andra världskriget blev det korta 1900talet. Retrospektivt kan vi säga att åren från I87I, efter fransk-tyska kriget och Pariskommunen, till det tidiga 2000-talet, blev till det långa 1900talet - från den europeiska industrialismens genombrott och dominans till att globaliseringen totalt utplånade tanken på en dominerande och helt självständig europeisk utveckling.

Det som förband början av det långa 1900-talet med dess slut var de oförlikneliga framstegen: den ekonomiska tillväxten, de omvälvande sociala reformerna, demokratin, välfärden. Det som lade ett tungt mörker över seklet var krigen och förtrycket.

Ofta sägs att vi inget vet om framtiden. Men så är det inte. Vi kan veta en hel del.

Industriell ekonomi och väl avgränsade nationalstater (och en hänsynslös exploatering av kolonierna) bestämde länge villkoren för samhällsutvecklingen i Västeuropa. Så är det inte längre och så blir det inte. Formell internationell samverkan och en globaliserad ekonomi förändrar villkoren. De sociala strukturer i Europa som byggt på en industriell produktionsordning och på absoluta nationsgränser håller på att lösas upp.

- Länge har det talats om en ohållbar relation mellan å ena sidan välståndets Västeuropa med en stagnerande befolkningsutveckling och å den andra sidan de omgivande staterna i framför allt Europas södra och sydöstra omland. Kombinationen i Nordafrika och västra Asien av svaga statsbildningar, snabbt växande befolkningar och fattigdom skulle förr eller senare leda till ett slags folkvandringsfenomen. Det vi under lång tid antagit skulle ske, sker nu. Omedelbart är det migrationskontrollens sammanbrott och rädslan för oro i Västeuropas sociala systemet som står i förgrunden. På lite längre sikt är det starkt 
tilltagande ekonomiska och sociala skillnader i bland annat flyktinginvandringens spår i Västeuropa.

- Vi vet att den tekniska utvecklingen forsätter i snabb takt och kommer att ge revolutionerande verkningar på stora och centrala samhällsområden. Det gäller medicinen och vår förmåga att förebygga, fördröja och bota sjukdomar. Tekniken kommer att finnas. Tillgängligheten för alla, rik som fattig, utgör det stora frågetecknet. Det gäller också den tekniska utveckling som kommer att revolutionera förutsättningarna för kontroll och övervakning. Det gäller över huvud den tekniska utvecklingens följder för allt från produktion av varor och tjänster till trafik och säkerhet. Möjligheterna är i det närmaste obegränsade.

- Samtidigt är riskerna med den tekniska utvecklingen och utslagningen av okvalificerade arbetsuppgifter uppenbara. Medierna är det första samhällsområdet som håller på att omvandlas i grunden till följd av den nya tekniken. Den traditionella dagstidningen, en och samma informationsbärare för alla i samhället, är redan död. Tidningen finns kvar, men inte tidningen som når alla. Den politiska offentligheten tycks utan återvändo komma att förgrovas och kommersialiseras. Det som redan har hänt på medieområdet kommer att hända på praktiskt taget alla samhällsfält. Allt annat än marknadshänsyn tenderar att tvingas vika. Jobb slås ut i mycket stor omfattning.

Det är lätt att teckna bilden av omöjligheter i det framtida samhället. Men framtiden är naturligtvis inte omöjlig. Däremot kommer den att bli annorlunda. Vi kommer att acceptera också detta. Det annorlunda blir normalt. För dem som flytt från norra Afrika till Europa är det en relativt sett god framtid som väntar. De blir inte välbeställda och likaberättigade medborgare i ett europeiskt välfärdsland. Men livskvaliteten blir en helt annan än i det land där flykten började. Och intressant nog: det förhållande att manuella arbetsuppgifter utförs av maskiner frigör mänsklig arbetskraft inte minst för utbildning, vård och omsorg. Det blir bättre för många av oss. 
Det är alltså verkligen inte sagt att vi som i generationer har levt i de västeuropeiska välfärdsdemokratierna kommer att få ett sämre liv. Men det blir ett annorlunda liv. Det räcker att ta metron från Saint-Augustin till Château d'Eau i Paris, eller från Karlaplan till Rinkeby i Stockholm, för att komma till det annorlunda samhället.

Vi har alltså mycket gott att vänta av morgondagen, inte minst till följd av den tekniska utveckligen. På viktiga samhällsområden har servicenivån och kvaliteten höjts avsevärt. Arbetskraft frigörs för att verka i vård och omsorg.

Men samhällsinstitutionerna sätts på prov. Vi kan se det i politiken, i den "politiska överbyggnaden", för att för att använda ett marxistiskt influerat uttryck men också i den offentliga verksamheten som sådan: i rättssystemet, i sjukvården och i skolan. Vi ser det inte minst i att den ekonomiska grunden för den offentliga verksamheten undergrävs. I rättsstaten ska medborgarna ha tillgång till de rättsliga institutionerna. Så är det inte i praktiken i dag. Än mindre kommer det att vara så i morgon. Kostnaderna är prohibitiva. Sjukvården kommer inte att vara jämnt fördelad. Delar av medelklassen köper sig ur ett solidariskt system där det halvbra håller på att bli norm. Psykiatrin har för länge sedan tappat kontakt med den verklighet som beskrivs i vårdpolitikens högtidstal. Skolan var segregerad långt innan privatiseringarna. Det är en effekt av en starkt segregerad bostadsmarknad. Med ökade sociala och ekonomiska skillnader är skolsegregationen oundviklig.

I en mening var det långa 1900-talet socialdemokratins, eller om man så vill arbetarklassens, sekel. Klassamhället ersattes alltmer av ett medborgarsamhälle där medborgarskapets likhet mellan människor blev mer karaktärsgivande än klassamhällets skillnader. Om än med dramatiska avbrott utvecklades de flesta europeiska samhällen mot en ökad och mer jämnt fördelad välfärd. Men denna utveckling är bruten sedan snart ett kvartssekel tillbaka.

Demokratins fiktion är att politiken styr. Det har alltid varit en fiktion men nu spricker den. Verkligheten närmar sig inte längre den 
socialdemokratiska utopin. Fiktionen om den demokratiska styrningen har kunnat vidmakthållas inte minst därför att det har legat i partiernas uppenbara intresse att vidmakthålla den. Vallöftet har varit "rösta på oss så förverkligar vi vårt program”. Och verkligheten förändrades länge i riktning mot det utopiska målet ett samhälle av alla och för alla. Så är det inte längre. Vi lever inte längre i ett samhälle $a v$ alla. Många unga män i Europas gamla industriregioner kommer aldrig att bidra till samhället. Detsamma gäller stora invandrargrupper. Vi lever heller inte i ett samhälle för alla. De sociala tjänster som en gång alla i våra samhällen hade rätt till kommer att successivt ransoneras allt hårdare. $\mathrm{Om}$ bland annat detta handlar reaktionen mot den stora invandringen i betydande delar av Europa.

Politiken styr inte och har inte styrt. Politiken har balanserat och fördröjt de stora förändringar som har drivits fram av teknik och ekonomi. Politiken har på så sätt givit legitimitet åt en utveckling som väsentligen har betingats av tekniska, ekonomiska och sociala krafter. Den stora samhällsbyggnadsmaskinen har styrts och programmerats av krafter utanför politiken, men politikerna har satt sig i förarsätet och vinkat åt väljarna och sagt: "Se vad vi kör, se så duktiga vi är!"

Detta kan låta som en odemokratisk eller rent av antidemokratisk verklighetsbeskrivning, men det är en beskrivning av demokratin sådan den faktiskt är. Den demokratiska politiken driver inte utvecklingen. Men det är inte detsamma som att demokratin skulle vara verkningslös. Demokratin är kontrollerande och gränssättande. Därtill finns det fält där den demokratiska politiken är helt avgörande för samhälleliga vägval. För att ta det viktigaste exemplet i vår tid: tillskapandet av EU, som från början och i många av de avgörande utvecklingsstegen är ett gigantiskt politiskt projekt. Demokratiskt valda politiker och det politiska skiktet i de europeiska samhällena har varit initiativtagare och svarat för genomförandet. Sedan kan förvisso sägas att den ursprungliga europeiska gemenskapen och dess utveckling till EU och den ekonomiska och monetära unionen väl harmonierar med kapitalismens inneboende internationalisering. Men det är inte liktydigt med att det var oundvikligt att Europas stater i denna historiska situation skulle sluta sig samman i ett nationsliknande förbund. 
Det som inträffar nu, eller rättare sagt har utvecklats i minst ett par decennier, är att den ekonomiska tillväxten inte längre på ett okomplicerat sätt paras med tilltagande jämlikhet. Kapitalinkomsterna ökar snabbt. Arbetsinkomsterna, inte minst för arbetare och lägre tjänstemän, halkar efter. Vi får en alltmer skiktad arbetsmarknad. Arbete som inte kräver kvalificerad utbildning flyttar till utvecklingsländer och nyindustrialiserade länder. De befolkningsskikt som av olika skäl inte kan uppfylla ständigt ökande produktivitets- och kompetenskrav ställs i betydande utsträckning vid sidan av. Det gäller rätt många ungdomar, det gäller medelålders och äldre människor som inte kan utveckla sin kompetens, det gäller stora invandrargrupper med svag utbildningsbakgrund från de samhällen som de har lämnat.

Det är svårt att se hur utvecklingen mot ökade sociala och ekonomiska skillnader skulle kunna vändas. Förvisso kan denna trend motverkas i enskildheter genom politiska beslut. Minskade kostnader för att anställa lågproduktiv arbetskraft (ett frånstötande uttryck, men likväl handlar det om just det) bidrar rimligen till att ett antal människor som annars inte skulle fătt arbete kommer att få det. Skolan kan förbättras - bättre villkor för lärarna gör att ett antal goda lärare som annars hade lämnat skolan blir kvar i läraryrket - även om det är en naiv föreställning att skolan som ett mycket stort och komplicerat kunskapssystem på något enkelt sätt förändras genom handgrepp på central nivå. Men ett bättre betygssystem är rimligen bättre än ett sämre.

Men dels verkar systemförändringar först på lång sikt, dels är systemet mycket komplext. Det är svårt att tänka sig att förändringar i politikens enskildheter skulle kunna mer än marginellt motverka verkningarna av de stora strukturella förskjutningarna i ekonomin: omfördelningen av arbete från höglöneländer till låglöneländer och de ständigt ökade kraven på arbetskraften i de postindustriella ekonomierna. 
Tillbaka till Marcel Proust. Hans stora romanverk handlar inte om en strävan att återvända till en tid som flytt. Han blickade bakåt för att beskriva det som är bestående mänskligt: kärlek, skönhetsupplevelser, familjerelationer, sorg, övergivenhet, statusjakt, tom materialism och inte minst social skiktning. Bakåtblicken skapade insikt om det som kommer att bestå och vara viktigt också i framtiden.

En övergripande insikt handlar om politikens institutioner, dess organisationer och partier. På gott och ont har tilliten till politiken varit mycket stor i Sverige. Vi har accepterat föreställningen om politikens primat: att politiken råder över ekonomin. I det tidiga skedet av upplösningen av Sovjetimperiet förekom begreppet "politikens primat" ofta i den intellektuella debatten. Förvåningen var stor över att makthavarna $\mathrm{i}$ Kreml så benhårt trodde på politikens primat - i grunden var det ju en borgerligt liberal föreställning. Själva kärnan i den marxistiska samhällsförståelsen var att utvecklingen i samhället berodde av materiella förhållanden: Hur ser produktionsprocessen ut? Hur förändras den till följd av att tekniska och sociala förhållanden förändras? Vilket förhållande till produktionsmedel och produktionsprocess har olika grupper? Och hur påverkas detta av att internationella förhållanden förändras?

Socialdemokratins ideologiska arv är marxistiskt. Men demokratin har helt fått ta socialismens plats.. Det var oproblematiskt så länge Socialdemokraterna framför allt representerade stora grupper industriarbetare och därtill kunde driva en socialreformistisk politik med hjälp av ständigt höjda skatter.

Men dominansen för en väl definierad industriarbetarklass har ersatts av en dominans för en synnerligen svårdefinierad medelklass, framför allt tämligen välutbildade människor som är anställda i offentlig sektor och i privat tjänsteproduktion och har medellåga inkomster. Parallellt härmed har den offentliga verksamheten expanderat starkt, och på så sätt blivit extremt viktig för alla i samhället, men samtidigt fått sådan omfattning att en vidare utbyggnad är allt annat än oproblematisk, framför allt för att det inte längre förefaller möjligt att höja skattetrycket. Med ett uttryck hämtat från Ansvarskommitténs arbete gick "utvecklingskraften" 
i den offentliga verksamheten förlorad. Ständiga reformer har ersatts av ständiga besparingar. Den sociala och politiska basen för socialdemokratisk politik undermineras. Det är uppenbart att socialdemokratiska regeringar inte kan styra samhällsutvecklingen som de vill göra.

Socialdemokratiska partier över hela Västeuropa försvagas strukturellt och för överblickbar tid framåt. Det gäller de socialdemokratiska partierna i Norge, Finland, Sverige, Tyskland, Österrike, Storbritannien, Frankrike, Spanien, Grekland. Det som en gång var 40-procentspartier är i dag i bästa fall 20-procentspartier.

Men intressant nog har de stora borgerliga partierna varit speglingar av en stark socialdemokrati. I retoriken har borgerliga partier sagt sig vara alternativet till Socialdemokraterna. I praktiken har borgerliga partier inte företrätt en helt annan politik. Mest talande är Folkpartiets slogan från valrörelsen i Sverige 1976: "Sociala reformer utan socialism!" Socialdemokratins samhälle skulle bestå men det socialdemokratiska partiet kämpas ned. Något egentligt alternativ till det socialdemokratiska samhälle som byggts under flera decennier erbjöds inte; också de borgerliga partierna var "välfärdspartier". Avgörande sociala problem skulle hanteras genom politiken. Därmed mötte och möter borgerlig politik i praktiken samma problem som den socialdemokratiska politiken. Det innebär dels att försvagade socialdemokratiska partier inte längre utgör den hotbild som gav styrka åt borgerliga motkraftspartier, dels att de realpolitiska problemen försvagar borgerliga partier precis på samma sätt som de försvagar socialdemokratiska partier.

Det nya i politiken blir framväxten av stora antietablissemangspartier, ofta med stark högerprofil och med invandringsfientlighet som ett bärande inslag. Det gäller Norge, Danmark, Frankrike, Österrike, Sverige, Finland, Storbritannien. Ett stabilt tvåpartimönster ersätts av ett trepartimönster. Varken höger eller vänster förmår bilda majoritetsregeringar.

Men inte bara partipolitikens institutioner försvagas. Det gör även statens institutioner och verksamhet: polisen, kommunikationsväsendet, skolan, socialtjänsten, socialförsäkringarna. Detta utgör i själva verket grunden för partipolitikens problem. Visst skulle det kunna ge borgerliga partier ökad trovärdighet när försvagningen av staten innebär att marknaden tar över. Men det är en starkt selekterande marknad. De allra 
flesta har mycket begränsade möjligheter att köpa de sociala tjänster som staten (det vill säga framför allt kommunerna) inte tillhandahåller.

Det är synnerligen viktigt att förstå förklaringarna till att utvecklingskraften i den offentliga verksamheten försvagas. Ett skäl har redan anförts. Skatterna har nått det som uppfattas vara ett tak. Höjs skatterna mer skadas konkurrenskraften för ett land som redan har ett högt skattetryck. Men detta räcker inte ensamt som förklaring. Med god ekonomisk tillväxt, som inte minst den tekniska utvecklingen bäddar för, borde utrymme skapas för en fortsatt reformverksamhet. Men det finns avgörande skillnader i produktivitetsutveckling mellan varuproduktion och tjänsteproduktion. Fenomenet är känt som Baumols dilemma. I grunden handlar det om att tjänster utförs av människor och varor produceras av maskiner. Det kommer att krävas lika många mantimmar för att vårda människor i äldreomsorgen 2060 som $\mathrm{i}$ dag. Samtidigt finns det ingen skönjbar gräns för den fortsatta rationaliseringen av produktionen av bilar, datorer, byggnadskomponenter eller kycklingkött. Det handlar alltså om skillnader ifråga om att kunna ianspråkta teknik. Men det handlar också om global produktion och en gränslös handel. Varor kan fraktas över långa avstånd till mycket låga kostnader. Varuproduktionen kan förläggas till länder där lönekostnaderna är låga. De händer som vårdar den sjuka eller gamla människan måste finnas där tjänsten utförs.

Visst finns det skillnader mellan produktion för marknaden och produktion inom ramen för offentliga monopolorganisationer. Men den skillnaden är på intet sätt avgörande. Därför är det inte en lösning på Baumols dilemma att privatisera och konkurrensutsätta offentlig tjänsteproduktion.

\section{6}

Sverige är sedan lång tid tillbaka ett utpräglat medelklassamhälle; folket utgörs av en egendomslös medelklass. Kännetecknande för den avancerade välfärdsstaten Sverige är att människors sociala ställning inte i huvudsak betingas av eget kapitalinnehav i traditionell mening utan att trygghet skapas genom offentliga välfärdsinstitutioner och andra lösningar vid sidan av marknaden, i synnerhet familj och släkt. Visst finns 
ett övre skikt i medelklassen som har sådana ekonomiska förutsättningar att de kan göra sig oberoende av välfärdsstaten med hjälp av eget kapital. Men också etablerade medelklassyrken ger en marginellt högre lön än de traditionella arbetaryrkena.

Det är knappast någon tillfällighet att den Moderatledda regering som tillträdde 2006 i väsentliga avseenden anknöt till den politik som den föregående socialdemokratiska regeringen drev. De gamla Moderaterna hade satt systemskiftet på dagordningen. De nya Moderaterna insåg att den absoluta merparten av de borgerliga väljarna var helt beroende av de sociala system som byggts upp under decennier och inte alls ville ha något systemskifte. Samtidigt förstod inte den borgerliga regeringen att ett bevarat och utvecklingskraftigt välfärdssystem krävde fortsatt höga - och på sikt högre - skatter. Därmed anslöt den sig till en borgerlig tradition sedan mitten av 1970-talet: en socialdemokratisk utgiftspolitik och en borgerlig skattepolitik. Aningen besynnerligt är att Socialdemokraterna efter maktskiftet 2014 i stor utsträckning har fortsatt på den inslagna vägen, även om en viktig förklaring är att Socialdemokraterna och de borgerliga vänder sig till samma sociala och ekonomiska skikt i samhället.

Men det finns en "kapitalrelation" som helt bryter detta mönster: boendet. De hyresstrejkande vänsterstudenterna i Lund i början av 1970talet förstod inte själva hur rätt de hade. Hela det etablerade skiktet i samhället tjänade då grova pengar på att bo. En av de ledande personerna i styrelsen för Akademiska föreningens bostäder var direktör i en av de större bankerna. I likhet med bankchefer över hela Sverige lånade han på en reglerad kreditmarknad ut pengar till sina villaboende "klasskompisar" mot en nominell ränta som motsvarande inflationen, då 6-7 procent. Denna ränta, som närmast definitionsmässigt motsvarade värdeökningen på villan, fick vid beskattningen dras av mot marginalskatten, för de ledande skikten i samhället då 85 procent. När villan sedan såldes var värdestegringen skattefri. Den som hade "goda bankkontakter", det vill säga tillhörde den etablerade medelklassen, kunde (för att belysa med ett tänkt exempel) köpa ett hus för 300 ooo kr, låna till hela köpet, dra av räntan, få en värdestegring på 21 $000 \mathrm{kr}$ och för detta bara betala $3000 \mathrm{kr}$ netto. I8 $000 \mathrm{kr}$ i årlig ersättning för att bo motsvarar 
I28 I50 kr i dag. Borgerligheten - socialdemokratisk såväl som borgerlig - fick betalt för att bo. Studenterna fick betala.

På den vägen har det inte varit sedan dess, men väl på liknande vägar. Enorma summor har omfördelats till dem som har från dem som inte har - till följd av knapphet på småhustomter, till följd av bestående orimligheter i skattesystemet, till följd av hyresregleringen, till följd av utförsäljning av allmännyttans bestånd av hyreshus till starkt subventionerade priser, till följd av avskaffad fastighetsskatt och till följd av restriktioner mot bostadsbyggande i storstadsområden. I spåren av denna bostadskapitalism har följt ett starkt segregerat samhälle med de sociala verkningar detta har medfört. Det behövdes inga privata skolor för att skilja rika barn från fattiga barn. Det har under snart ett halvsekel skötts av en synnerligen illa fungerande bostadsmarknad.

Detta är historia men också nutid. Lönearbetet är inte alldeles lätt att i dag se som en stratifierande faktor vid bestämmandet av sociala förhållanden och den politiska representationen. Däremot är bostadsägandet en extremt viktig faktor. Därför vågar inte något av de viktiga partierna förorda det självklara: att fastighetsskatten ska återinföras.

Det andra området där förhållandet till kapitalet är socialt avgörande är pensionerna. I folkomröstningen 1957 fick Socialdemokraternas linje I mest röster och riksdagen fattade beslut i enlighet med det alternativet. Därefter har linje 2 och 3 genomförts. Av ATP-systemet blev en grundtrygghet. De avgörande skillnaderna har skapats av ett system som är helt kopplat till anställning. Men "pensionskaptalismen" ger inte riktigt samma klasskiljande effekter som bostadskapitalismen. På hela arbetsmarknaden har avtalspensioner kompletterat folkpensionssystemet och ATP-systemet.

\section{7}

Långtidsutredningen 2015 visar genom ett basscenario att BNP i Sverige kommer att fördubblas fram till 2060. Vi vet att människor vill lägga en större andel av sin inkomst på sociala tjänster - vård, omsorg och utbildning - när inkomsterna ökar. Likväl innebär långstidsutredningens prognoser att den reala konsumtionen av sociala tjänster inte kommer att 
hålla jämna steg med traditionell privat konsumtion. Det genomsnittliga svenska hushållet skulle 206o ha fler bilar och fler datorer än i dag men ha kvar sjukvård och äldreomsorg av 20I5 års kvantitet och kvalitet.

Så kommer det knappast att bli. Men inget politiskt parti har över huvud taget någon idé om hur en annan utveckling ska kunna komma till stånd.

Man kan antyda två alternativa utvecklingslinjer.

- Vi gör upp med föreställningen om ett skattetak vid nivån 50 procent av BNP. Det är i första hand en teknisk fråga hur skatterna ska kunna fortsätta att höjas, på lång sikt sannolikt till att motsvara 70 eller 80 procent av BNP. De stora potentiella skatteintäkterna ligger hos medelklassen. Konsekvensen blir rimligen att de riktigt låga inkomsterna blir lågt beskattade. Medelinkomsttagarna blir genom inkomstskatt, mervärdesskatt och fastighetsskatt mycket högt beskattade. Men skattekonkurrens mellan olika länder är en realitet. Vi har redan i dag tagit konsekvenserna av detta i det att vi har en låg kapitalbeskattning. En skenbar paradox i en framtida högskattepolitik blir därmed att marginalskatten på höga förvärvsinkomster blir regressiv och låg. Vi klarar på så sätt ett betydligt högre skattetryck och därmed finansieringen av en utvecklingskraftig välfärdssektor samtidigt som Sverige blir attraktivt för det internationellt rörliga kapitalet och den riktigt kvalificerade arbetskraften som rör sig på en helt öppen global arbetsmarknad. Men detta alternativ förutsätter ett mycket starkt och handlingskraftigt politiskt system.

- Det andra alternativet är att bristen på handlingskraft består. En förenklad fördelningssyn fortsätter att bestämma skattepolitiken. Ingen vågar röra fastighetsskatten. Den något besynnerliga idén att inkomstskatterna ska vara låga för dem som har allra störst intresse av en fungerande välfärdsstat fortsätter att sätta mycket snäva ramar för finansieringen av välfärden. Ingen vågar tänka tanken på en högre och bredbasig mervärdesskatt därför att mervärdesskatten är regressiv och impopulär. Sammantaget avsvär vi oss möjligheterna att på ett avgörande sätt höja skattetrycket. Vi backar in i framtiden med blicken fäst vid det som var. Den offentliga verksamheten lever under 
en allt kallare stjärna och förlorar utvecklingsförmåga och kvalitet. De som har det lite bättre ställt köper sig i viss mån ur de offentliga välfärdssystemen. Vi kommer att se mer av anställningsanknutna sociala försäkringar. Men många ställs utanför. Och kvaliteten i stora delar av såväl välfärdssektorn som i offentlig verksamhet av mer traditionellt slag - offentlig förvaltning, rättsväsende, försvar, infrastruktur - kommer att vara djupt otillfredsställande.

I det senare alternativet kommer politiken fortsätta att förlora sin relevans. De traditionella partierna förlorar därmed successivt sin attraktionskraft. Besynnerligt nog kommer partierna i detta senare alternativ att vara överens om en politik vars resultat ingen vill ha. Den enskildes egna resurser, det egna kapitalinnehavet i vid mening, får stor betydelse. Bristen på jämlikhet blir uppenbar. Men de allra flesta kommer att förlora i relativ social trygghet.

Om man på allvar vill försöka utforma en framtida högskattepolitik som är en förutsättning för en utvecklad välfärdspolitik - är bostadspolitiken och den skattemässiga regleringen av boendet ett avgörande problem. Ska den lägre medelklassen belastas med avsevärt mycket högre skatter kan inte boendet fortsätta att skapa hål i skattesystemet för den bostadsägande lite högre medelklassen.

\section{9}

Tillbaka till Göran Therborns fråga: Ställer sig medelklassen med oligarkin mot de fattiga eller med folket mot oligarkin?

Sannolikt är att medelklassen i de västliga samhällena krackelerar. Inkomstskillnaderna ökar. De nya jobben ger högre inkomster för ett relativt fåtal och lägre inkomster för många. Detta skulle tala för att den sociala basen för det traditionella partisystemet återskapas. Samtidigt kommer inte de högre inkomsterna att bli så höga att de skapar oberoende i förhållande till välfärdsstaten. En allians med oligarkin hjälper inte medelklassen särskilt mycket. 
Avgörande för utvecklingen blir hur olika politiska krafter ställer sig till skattepolitiken. Problemet är att en lågskattepolitik alltid är attraktiv på kort sikt men att dess effekter egentligen inte lockar någon på längre sikt. Viktiga delar av den politiska borgerligheten föreställer sig nog att det finns ett marknadsekonomiskt alternativ till välfärdsstaten och att staten snarare är en fiende än en allierad. Men den tanken leder till samma typ av utopism som tanken att staten skulle ersätta marknaden en gång gjorde.

Medelklassen i Europa kan inte under överblickbar tid göra sig oberoende av välfärdsstaten. Politiskt har detta visat sig i Sverige alltsedan I980-talet. Någon politik för ett systemskifte har över huvud taget aldrig preciserats. Det nya hos de nya Moderaterna var att de erkände detta.

Den nuvarande politiska strukturen verkar inte förmå hantera de utmaningar som välfärdsstaten står inför. Ovan talade jag om föreställningen om "politikens primat". Politikens problem är delvis betingat av att den har lämnats ifred alldeles för mycket. Det går nog inte att förutse hur den politiska strukturen kommer att förändras, hur den måste förändras. Det handlar inte om att ersätta demokratin med något annat, snarare om att fördjupa demokratin. Den vackra föreställningen om medborgarna som härskare i demokratin förutsätter nog att vi som medborgare också deltar i folkstyret.

Deltagande gav kraft åt arbetarrörelsen, långt senare åt den gröna rörelsen. Nu tycks det främst ge kraft åt en invandringsfientlig reaktion. Förr eller senare blir det dags för den upplysta medelklassen att ta ansvar för det samhälle som den vill leva i. Framtiden kommer inte att ställas in. Den är inte oförutsebar. Det går att förstå vad som håller på att ske. Framtiden går att påverka.

Är detta blott en from förhoppning, en liberal dröm om kraften hos människors idéer och ideal? Nej, snarare en tämligen krass slutsats om hur breda grupper kommer att reagera när deras välfärd och trygghet undergrävs och de inser att ingen annan kommer att lösa deras problem. Det var inte i första hand ideal som gjorde att den svenska arbetarklassen en gång organiserade sig, den drevs av ett mycket starkt egenintresse. Varför skulle en bred medelklass mer än hundra år senare agera annorlunda? 


\section{Referenser}

Baumol, William och William Bowen (1966). Performing arts. The economic dilemma. A study of problems common to the theater, opera, music, and dance. New York: Twentieth Century Fund.

SOU 2003:123. Utvecklingskraft för hållbar välfärd. Delbetänkande från Ansvarskommittén.

SOU 2007:IO. Hållbar samhällsorgansation med utvecklingskraft. Slutbetänkande från Ansvarskommittén.

SOU 2015:I04. Långtidsutredningen 20I5. Huvudbetänkande från Långtidsutredningen.

SOU 2015:106. Sveriges ekonomi - scenarier fram till år 2060. Bilaga I till Långtidsutredningen.

Svegfors, Mats (2009). Sjukvård i den mogna välfärdsstaten. Rapport till Socialdemokraternas långtidsutredning 2009.

URL: https://www.socialdemokraterna.se/upload/Central/dokument/pdf/

Langtidsutredningen/Mats_Svegfors.pdf (6 september 20I6)

Therborn, Göran (1989). Borgarklass och byråkrati i Sverige. Anteckningar om en solskenshistoria. Lund: Arkiv förlag.

Therborn, Göran (I99I). "Swedish Social Democrats and the transition from industrial to post-industrial politics", i Frances Fox Piven (red.), Labor parties in postindustrial societies. Cambridge: Polity Press.

Therborn, Göran (20I4). "Klass i det tjugoförsta århundradet”, i Arkiv. Tidskrift för samhällsanalys, nr 3.

DoI: http://dx.doi.org/IO.I3068/2000-6217.3.3

Therborn, Göran (20I4). "Nya massor? Motståndets sociala grundvalar", i Arkiv. Tidskrift för sambällsanalys, nr 3.

DOI: http://dx.doi.org/10.13068/2000-6217.3.4

Therborn, Göran (2015). "Globaliseringen": historien, nationalstaterna och framtiden. Föreläsning i Lunds filosoficirkel 28 april 2015. URL: https://www.youtube.com/watch?v=mpSTtBpfdu4 (6 september 20I6) 


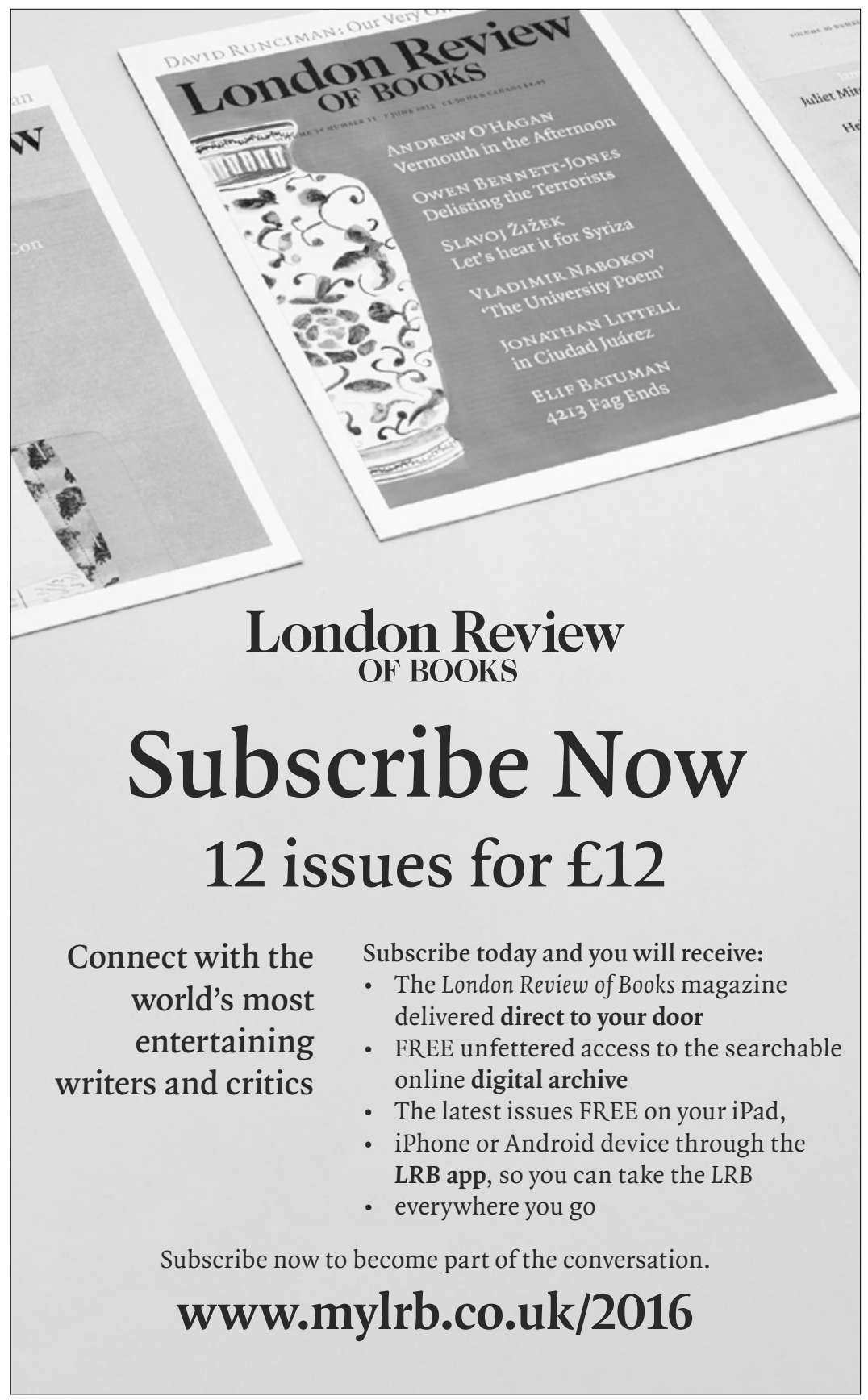

